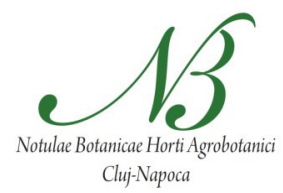

\title{
Forest Administration in Romania: Frequent Problems and Expectations
}

\author{
Mihai MARINCHESCU ${ }^{1}$, Aureliu Florin HALALISAN ${ }^{1}$, Bogdan POPA ${ }^{1}$, \\ Ioan Vasile ABRUDAN ${ }^{1,2 *}$ \\ ${ }^{I}$ Transilvania University of Brasov, Faculty of Silviculture and Forest Engineering, 1 Sirul Beethoven Braşov, \\ Romania;marinchescu_mihai@yahoo.com; halalisanaureliuflorin@yahoo.com;popab03@gmail.com \\ ${ }^{2}$ Academy of Romanian Scientists, 54 Splaiul Independentei, Bucuresti, Romania; abrudan@unitbv.ro ('corresponding author)
}

\begin{abstract}
The aim of this study is to describe the status and evolution of forest administration in Romania in terms of forest regime, as well as to highlight the most frequent problems and common expectations of forest district managers. Underlying the presented results are an analysis of the compiled statistical indicators used in Romanian forestry and the outcome of a sociological survey conducted on a sample of 345 forest district managers. In early 2013, over 4.4 million hectares of state, public and private forest land were administered by state and experimental forest districts, and over 1.7 million hectares of forest land, other than state-owned, by private forest districts. Note that approximately 0.36 million hectares (over $5 \%$ of Romania's forest area) are not in the administration of specialized units, contrary to the legal provisions. The most frequent problems faced by forest district managers arise in relation to the owners of forests or are caused by illegal logging. This study is a contribution to making the concrete problems faced by foresters and especially the structure and ownership related characteristics of forestland the driving force of legislative changes in the forestry sector.
\end{abstract}

Keywords: ownership, private forest district, silviculture

\section{Introduction}

Transition to market economy has also triggered the restitution of forest lands in many Eastern and Central European countries (Bouriad and Schmithusen, 2005; Wiess et al., 2012), including Romania. In 1948, during the communist regime, in Romania forests belonging to individuals ( $23 \%$ of the total) and to local communities and other legal entities ( $49 \%$ of the total) were nationalized (Poynton et al., 2000; Ungur, 2008). The implementation process of the laws on forest restitution started after the fall of communism has no led to the re-establishment of the 1948 structure of property (Bouriad 2001; Lawrence and Szabo, 2005; Marinescu, 2005; Marinescu, 2007; Bouriad, 2008; Abrudan et al., 2009; Abrudan, 2012). Thus by mid2014, more than 3.2 million ha of forest land (49\% of the total forest area of Romania) was still state owned (RNP Romsilva, 2014). More than two decades after the launch of forest restitution the process is still not completed (Marinchescu and Halalisan, 2014), the state owning forest lands by more than 1 million ha greater than those before 1948.

The transition has been a challenge also to the forestry institutions of some countries (UNECE and FAO, 2011), including Romania, where the forestry sector has undergone major institutional transformations. Initially, the Romanian Ministry of Forestry founded in 1948 coordinated 467 forest districts set up to ensure the security, management, protection and development of the forests across the entire forested area of the country (Ungur, 2008). In 1990, upon the regime change, forest administration was assigned to Romsilva - the State Forest Administration, including about 360 forest districts (Abrudan et al., 2009). The 1996 Forestry Law and subsequent regulations provide for the first time the possibility of forests that are not state-owned to be managed by "own structures similar to state ones", namely by private forest districts (Machedon, 1999). These legal provisions refer to forest lands that are jointly owned undivided property and to forest lands owned by administrative-territorial units. Bouriaud (2001) notes the interest shown at that time by the Association of Forest Owners of Romania (APPR), including associations of forest owners from the entire country, to provide private forest owners with non-state management structures (represented by the Romsilva state forest districts). The first regulation on the establishing, organisation and functioning of private forestry structures was issued in 1999 (Government Decision 997/1999) (Tobescu, 2004), followed 2 years later by Government Order 116/2002 providing for forest owners in Romania the possibility to establish private forest districts. Consequently by the end of 2002 a number of 25 private forest districts were functioning nationwide (Tobescu, 2004). 
Tab. 1. Questions included by the questionnaires disseminated to the forest district managers

\begin{tabular}{|c|c|}
\hline Question & Target variables \\
\hline To what types of forest does the private/state forest district managed by you provide forestry services? & Surface area by type of property: \\
\hline $\begin{array}{l}\text { Which is the dominating category of services provided by the forest district managed by you (related } \\
\text { to the number of ha)? }\end{array}$ & Share of: i) forestry services and ii) administration \\
\hline $\begin{array}{l}\text { As part of your forestry activity, which is the problem caused by natural phenomena }(5) \text { you encounter } \\
\text { most frequently? }\end{array}$ & Share of problems caused by natural phenomena: \\
\hline $\begin{array}{l}\text { In your activity, which is the technical forestry problem (except natural phenomena) you encounter } \\
\text { most frequently? }\end{array}$ & Share of problems other than natural phenomena: \\
\hline $\begin{array}{l}\text { As part of your forestry activity, which is the problem concerning the relationship to the owners of the } \\
\text { forests you manage that you encounter most frequently? }\end{array}$ & $\begin{array}{l}\text { Share of problems encountered in the relationship } \\
\text { to forest land owners: }\end{array}$ \\
\hline $\begin{array}{l}\text { As part of your forestry activity, which is the problem concerning the relationship to state institutions } \\
\text { (7) that you encounter most frequently? }\end{array}$ & $\begin{array}{l}\text { Share of problems encountered in the relationship } \\
\text { to state institutions: }\end{array}$ \\
\hline $\begin{array}{l}\text { As part of your forestry activity, which is the illegal activity (4) that you encounter most frequently } \\
\text { and who causes this problem? The illegal activity is caused by: }\end{array}$ & $\begin{array}{l}\text { Share of illegal activities faced by forest district } \\
\text { managers: }\end{array}$ \\
\hline Which category of problems affects most your activity at the forest district? & $\begin{array}{l}\text { Share of the most important problem in the activity } \\
\text { of the forest district: }\end{array}$ \\
\hline $\begin{array}{l}\text { In order to conduct better forestry management, do you need improved activity, competence, } \\
\text { communication and involvement of? }\end{array}$ & Shat \\
\hline
\end{tabular}

The current Forestry Law passed in 2008 defines 4 categories of forest land ownership: i) public state property (PPS), ii) public property of administrative-territorial units (PPUAT), iii) private property of administrative-territorial units (PPRUAT) and iv) private property of individuals and legal entities (PPRPFJ). The same deed regulates forest management in Romania, by Romsilva state forest districts and private forest districts, established by forest land owners others than the state.

All these changes in forest land property and administration have created numerous challenges for both state and private forest administration structures. To date varies studies have addressed the evolution, status, silvicultural, economic, social and environmental issues faced by both state and private forest districts in Romania, featuring rather tangential approaches (Lawrance and Szabo, 2005; Ioras and Abrudan, 2006; Abrudan et al., 2009), but also dedicated ones (Abrudan 2012, Marinchescu et al., 2013), that can offer important information on the characteristics of forest administration structures. In such a volatile environment, however, the need persists for up-to-date and founded information on the evolution and challenges of forest land management.

It is within this context that this paper aims at describing the evolution of forest land administration in Romania after a decade of parallel functioning of state and private administration structures, and to reveal the most frequent problems and expectations of managers working within these.

\section{Materials and methods}

The data on the forest land areas managed by private districts broken down by categories of owners were obtained from the Silv 1 questionnaires returned by the private forest districts between July and September 2012 and made available by the 9 Territorial Forestry and Wildlife Inspectorates (ITRSV). Silv 1 questionnaire includes, i.a. the surface area of the forest lands by categories of owners, is filled in annually by the forest district, validated by the competent ITRSV and centralized by the National Institute for Statistics (INS, 2013) that publishes the data by county and nationally.
The data on the surface area of the forest land administered by state districts were provided by the Romsilva Annual Report for 2013. The data on the national forest land surface was provided by the INS Annual Report. Based on the collected information, for the first time in Romania a national statistic on the type of forest management and administration was devised with the same calendar date as point of reference - 31 December 2012.

In order to identify certain characteristics, frequent issues faced by the managers of forest administration structures, as well as their expectations from various categories of factors of interest, a sociological survey was conducted on a sample of 392 private and state forest district managers from counties where both structures operate in parallel ( 28 counties of a total of 41 ). The development of method, techniques, procedures and instruments used for the sociological research drew upon a vast amount of literature (Marginean, 2000; Babbie, 2007; Chelcea, 2001; Marsden and Wright, 2010).

The questionnaire for the forest district managers was based on the qualitative analysis conducted by the authors between 2012 and 2013 on the occasion of the general biannual assemblies of the Forest Administrators Association (AAP), an organisation the main objective of which is representing the interests of its more than 90 member private forest districts. The qualitative analysis was carried out by means of focus groups and was aimed at identifying and enumerating the main problems of forest district managers on one hand, and of the categories of involved factors who by improving their activity could determine an increase in forest management quality on the other. The focus groups consisted only of representatives of private forest districts, it being assumed that the problems and expectations of these managers should not differ significantly from those of state forest districts, as the forest regime does not depend on the type or ownership of forest lands. The questionnaire design (questions featured in Tab. 1) was completed based on the results of the qualitative analysis.

Thus, in order to reveal the characteristics of interest 2 closed-ended questions were included, while 6 questions (5 open-ended and one closed-ended) were aimed at identifying the problems. The expectations from the factors of interest were determined by means of a ninth question in matrix form, 
including 9 closed-ended sub-questions for the established 9 categories of factors.

The questionnaire was piloted on a sample of 10 managers of 8 private and 2 state forest districts. Its results were used for refining the questions. Subsequently the questionnaires were sent to the managers of private forest districts by mail, to the respective district's address. The period of questionnaire administration was between October and December 2013. In the case of state forest districts the questionnaires were distributed via the Romsilva central office by e-mail to district managers. The questionnaires were sent only to state forest district managers in counties including also private forest districts. The action was initiated in January 2014 and the questionnaires were returned by March.

Upon return of the questionnaires, the data were coded and fed into a database in MS-Excel, followed by statistical processing by means of the dedicated STATISTICA software application.

\section{Results and discussions}

\section{The evolution of forest lands administration by type of ownership}

According to INS reports the surface of forest lands in Romania has increased from 6,371 thousand ha in 1990 to 6,538.5 thousand ha in 2013. At the same time, over a decade of functioning the private forest districts have known continuous and swift development as to their number and managed surface. While in 2002 a number of 25 entities managed 250 thousand ha of forest land (Tobescu, 2004), only 4 years later, in 2006 it was 104 private forest districts managing 1,091 thousand ha (approximately $17 \%$ of the total of lands) (Abrudan and Dutca, 2006). In January 2011 more than 132 private forest districts were managing 1,529 thousand ha forest lands (Abrudan, 2012). The documentary analysis conducted by the authors shows that on 31 December 2012 a number of 139 private forest districts were managing more than 1,733 thousand ha nationwide (26.5\% of the national forests).

Fig. 1 shows the situation of forest lands management in Romania at the end of 2012. Thus, the state forest districts were managing 4,362.5 thousand ha nationwide, of which 3,234.1 thousand ha state-owned and 1,128.4 thousand ha belonging to other owners, management being provided by service contracts; the experimental forest districts of the Forest Research and Management Institute (ICAS) were managing 72.5 thousand ha (49.2 thousand ha state-owned and 23.3 thousand ha belonging to other owners). Property other than state-owned was predominantly $(53.4 \%$, i.e. 1733.3 thousand ha) managed by private forest districts, followed by administration by state forest districts $(34.8 \%$, i.e. 1128.4 thousand ha), and experimental forest districts $(0.7 \%$, i.e. 23.3 thousand ha), while the remaining $11.1 \%$ (360.8 thousand ha) were not administered by any forestry structure, contrary to the legal provisions in force.

Fig. 2 shows for the years 2006, 2010 and 2012 the situation of forest district administration of forest lands not in state ownership. At the end of 2006, after approximately 4 years of private management, about $47 \%$ of the non-state forest lands were managed by private forest districts. By type of ownership these forest lands included: 538 thousand ha (62\% of the total) PPUAT-owned and 560 thousand ha (38\% of the

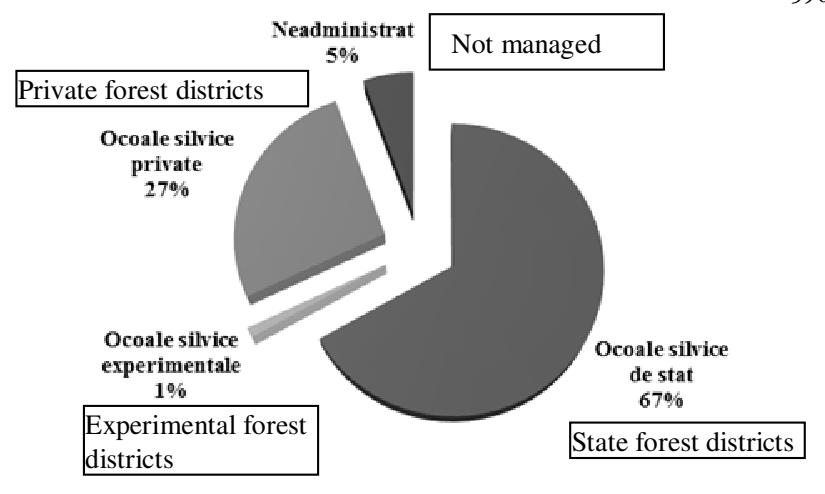

Fig. 1. Management of forest lands in Romania by categories of forest district

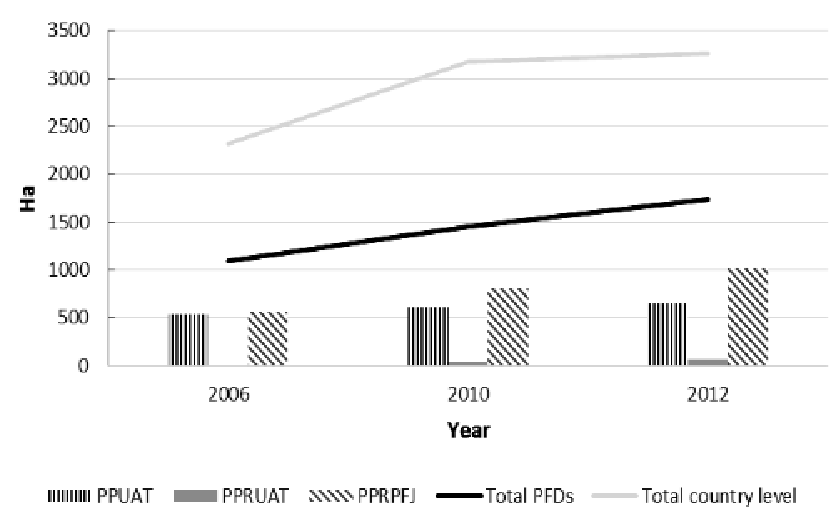

Fig. 2. Evolution of the structure of forestland managed by private forest districts (Abrudan and Dutca, 2006; RCA, 2013; RNP, 2013)

total) PPRPFJ-owned (joint ownerships, communities, churches, education establishments, individuals or associations of individuals).

By the end of 2010 the total PPUAT-owned forested area recorded a significant increase exceeding a million hectares, of which 59\% (606 thousand ha) were managed by private forest districts. The total national area of PPRPFJ-owned forest also grew significantly; while the percentage of private forest district managed areas did not change relevantly between 2006 and 2010, the area increased by more than 250 thousand ha. At this time PPRUAT ownership was to be taken into consideration as well, where of the total of 73 thousand ha, 42 thousand ha (58\%) were managed by private forest districts. By the end of 2012, 63\% of the PPUAT-owned, $84 \%$ of the PPRUATowned and $47 \%$ of the PPRPFJ-owned forest lands were managed by private forest districts. Considering that the 360.8 thousand ha that are not subject to forestry regime are PPRPFJ-owned, it can be said that private forest districts are preponderant for this category too.

\section{Problems and expectations of forest district managers}

The response rate for the survey

The return rate of the disseminated questionnaires was of $88 \%$, a figure that broken down for the two categories of forest districts yields: i) 111 private forest district managers $(81 \%$ of the total of private forest district managers questioned) proved receptive to the request of filling in the questionnaires; of the initial 139 identified structures 2 were dissolved during the 
591

period of study, thus reducing the sample to 137 private forest district managers; ii) 234 state forest district managers ( $92 \%$ of the total number of disseminated questionnaires) returned these.

\section{Forest land management by type of property}

Processing of the data collected via the questionnaires revealed that $32.2 \%$ of the total questioned private forest districts and $36.8 \%$ of the questioned state-owned ones manage forest lands owned by towns and cities. It further followed that $64 \%$ of the total questioned private forest districts and $76.9 \%$ of the questioned state-owned ones manage forest lands owned by village halls. Taking into consideration the management structure of forest lands by ownership as discussed in the previous section of this paper (nationwide private forest districts manage $63 \%$ of PPUAT-owned and more than $84 \%$ of PPRUAT-owned forests), it follows that although a smaller number of private districts manage forests owned by administrative-territorial units, the respective property areas are significantly greater than the same type of property areas managed by state forest districts. Thus the great forest land owners of this category are affiliated to private forest districts rather than state-owned ones.

The results obtained in relation to jointly owned undivided property (e.g. joint ownerships) revealed that $59.5 \%$ of the questioned private and $47 \%$ of the questioned state forest district districts manage such property. It further followed that $65.8 \%$ of the questioned private and $72.5 \%$ of the questioned state forest district districts manage forest lands belonging to churches, education units and other legal entities. $93.6 \%$ of the questioned private and $69.4 \%$ of the questioned state forest districts manage forests belonging to individuals and associations of individuals. Finally, $19.8 \%$ of the questioned private and $9 \%$ of the questioned state forest districts manage forest lands of foreign individuals and legal entities with foreign capital.

As shown above, $47 \%$ of forest lands owned by individuals and legal entities were managed by private forest districts by the end of 2012. Taking into consideration the 360 thousand ha of this category of ownership that are not managed, it can be asserted that the property of individuals and legal entities managed by private forest districts is greater than forest property managed by state forest districts. Thus also in the case of this type of property, the great forest land owners are affiliated to private forest management.

Further it needs be mentioned that 43 districts of the total of 345 questioned manage forests owned by foreign individuals and legal entities with foreign capital. Although nationwide no detailed data were available about the standing of the individuals and legal entities who benefitted from forest land restitution, the 43 received answers show to a certain degree that Romanian forest property undergoes alienation to foreign individuals and legal entities with foreign capital.

\section{Categories of services provided by the forest districts}

For the non-state forest property subject to the study it followed that the provision of services dominates with 212 answers (61.45\% of the total) (Fig. 3), revealing that forest land owners while interested in the acquisition of forestry services required by the forestry regime (protection of the forest, valorisation of the wood mass, planning of afforestation, management of tree stands, etc.), prefer to self-manage their income and expenditure related to forest management.
An analysis by the two categories (Fig. 3) reveals that private forest districts provide mostly administration services, in accordance with their object of activity, while state forest districts provide services other than administration. These results, closely linked to those obtained at the first question prove that the owners of large forest areas included in the study tend towards integrated forest land administration by private forest districts. The preference for acquiring only forestry services from state forest districts is generated mainly by the small size of the concerned properties the owners of which are frequently satisfied to meet their families' need of wood. Although this aspect requires further study, the analysed responses allow for the conclusion that the process of forest district establishing and development is closely linked to the initiatives and leadership abilities of the forestry personnel in the respective region, to earn the trust of forest owners, who on their turn accept support for ensuring the legal and efficient management of their forest lands.

\section{Problems caused by natural phenomena}

The dieback of trees was the problem caused by natural phenomena most frequently indicated by the questioned forest district managers (38.74\% of the questioned private districts and 49.57 of the questioned state districts) (Fig. 4). The main dieback causes, according to the received responses, are draught and forest pest attacks. Second after this category of problems are trees felled and torn, typically caused by abundant snowfalls and violent winds. Other problems, however less frequently mentioned by the respondents are the road infrastructure degradation and long periods of thick layers of snow covering the roads.

\section{Technicalsilvicultural problems}

The most frequent technical problems indicated by the managers of private forest districts are determined by inadequate legislation (12.61\%) and the achievement modalities of technical forest management and forest cadastre (11.71\%) (Fig. 5). The managers of state forest districts, with the exception of those who did deem to face these issues, frequently signaled problems caused by forest management and forest cadastre (8.12\%) (Fig. 5).

\section{Problems concerning the relationship to forest land owners}

The managers of private forest districts are most frequently confronted with pressure for making profits by breaching the forestry regime (Fig. 6). On the other hand $23.5 \%$ of the respondent managers of state forest districts signal the problem of financial honouring of the forestry services contracts (Fig. 6). Both situations are easily explained by the owners' patrimonial interest. The pressure for making profits by breaching the forestry regime is also a problem for state forest district managers, as well as the lack of forest management knowledge for forest owners (Fig. 6).

In the case of private forest districts the problem of meeting the population's need for wood appears as a problem within the already mentioned context of the large properties of villages/towns managed by private districts. Also interesting is that $9 \%$ of the managers of private forest districts have problems with owners who wish to increase their profit by minimising the forest district operational costs, a situation confirmed by the owners' patrimonial interest taking precedence over due care for ensuring forest continuity. The responses falling into this category came mostly from private forest districts involved predominantly in the provision of services rather than administration. 
Factor: private forest district manager

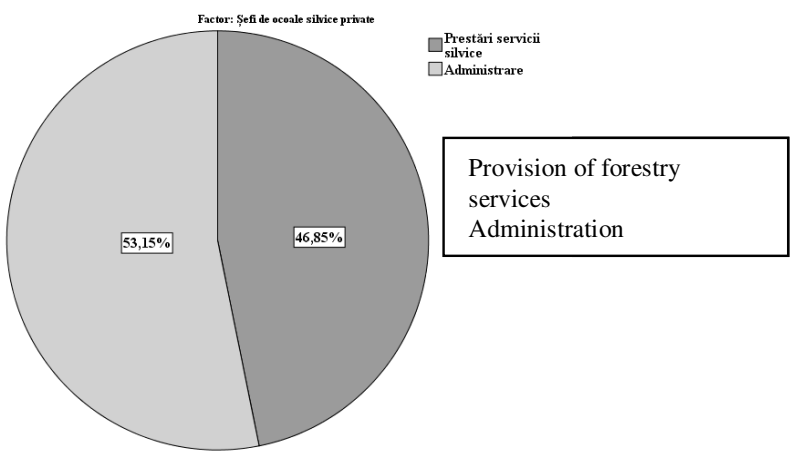

(a)
Factor: state forest district manager

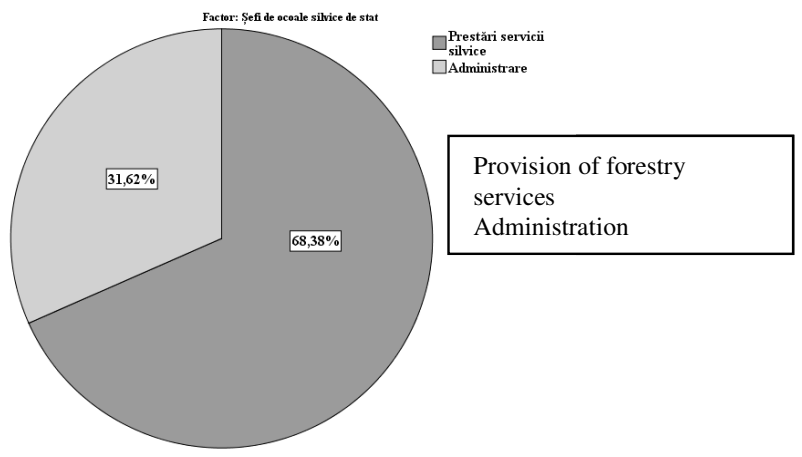

(b)

Fig. 3. Share of forestry services provided by forest districts: (a) private and (b) state

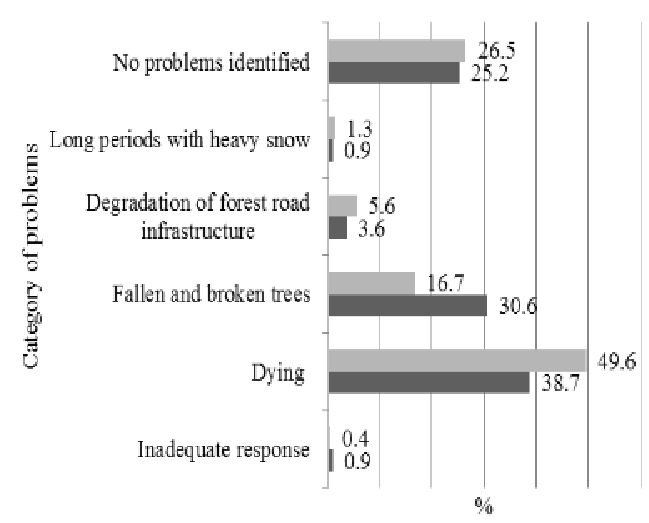

Fig. 4. The most frequent problems caused to forest districts by natural phenomena

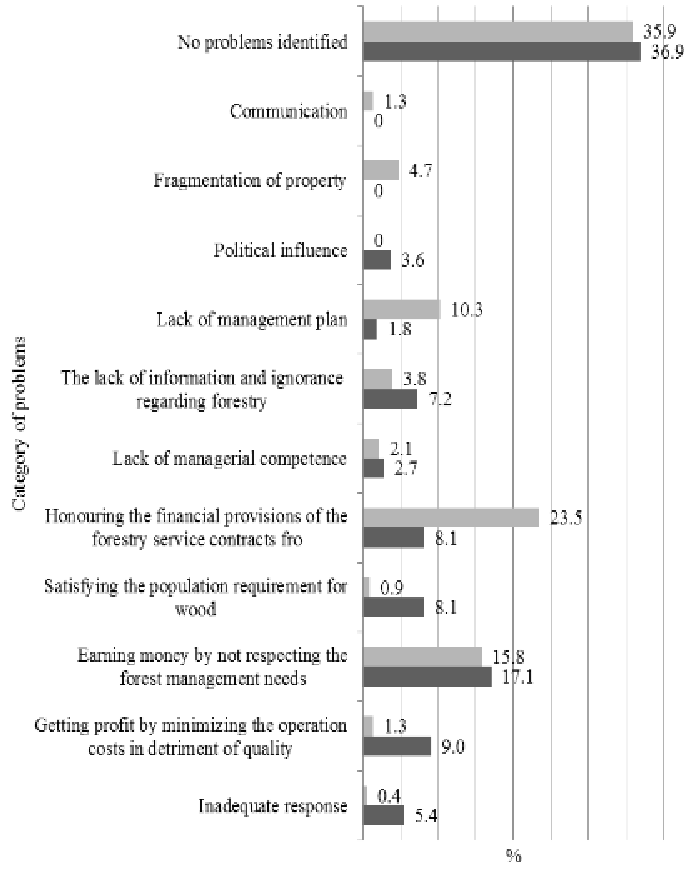

Fig. 6. The most frequent problems of forest districts in their relationship to forest owners

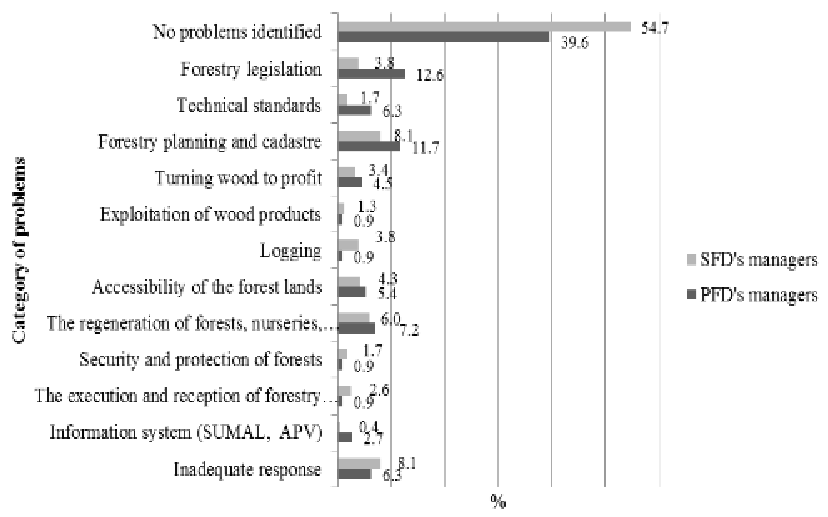

Fig. 5. The most frequent technical forestry problems caused to forest districts

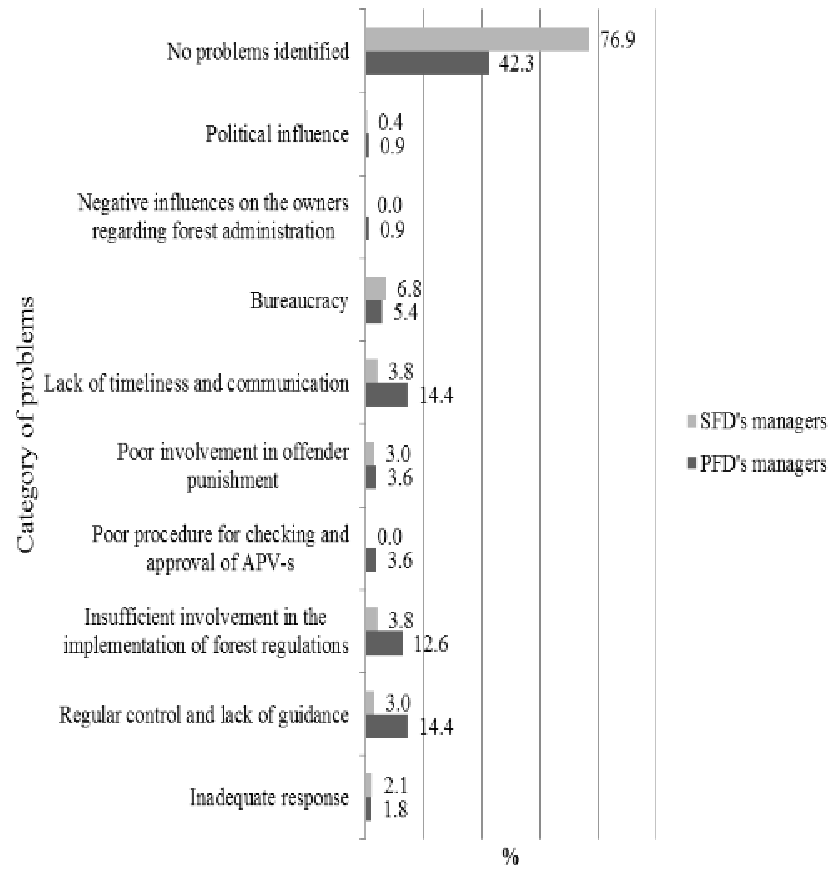

Fig. 7. The most frequent problems of forest districts in their relationship to state institutions 
593

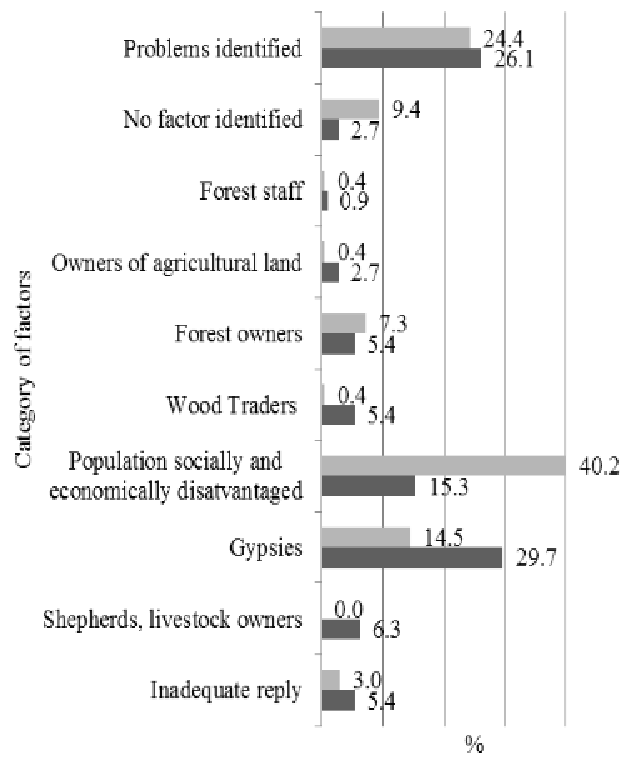

(II SFD's managers - PFD's managers

Fig. 8. The most frequent problems caused to forest districts by illegal activities: (a) private and (b) state

\section{Problems concerning the relationship to state institutions}

Of the questioned managers of state forest districts $76.92 \%$ did not mention any problems pertaining to this category (Fig. 7). This very large number of non-responses is due to the state forest districts being perceived by the respondents as institutions falling under state authority. A problem signalled by 16 managers of state forest districts is bureaucracy. Of the private forest district managers $43.34 \%$ claim not to encounter problems with state institutions. The rest of the respondents indicated problems falling into the categories: frequent inspections and lacking guidance (16 respondents), lack of promptness and communication (16 respondents) and insufficient involvement in the implementation of legislation and of the forestry regime (14 respondents). The managers of private forest districts thus demonstrated more willingness to disclose insufficiencies in relation to state institutions, what is indicative of a certain degree of independence.

\section{Problems caused by illegal activities}

A number of 225 forest district managers from the area

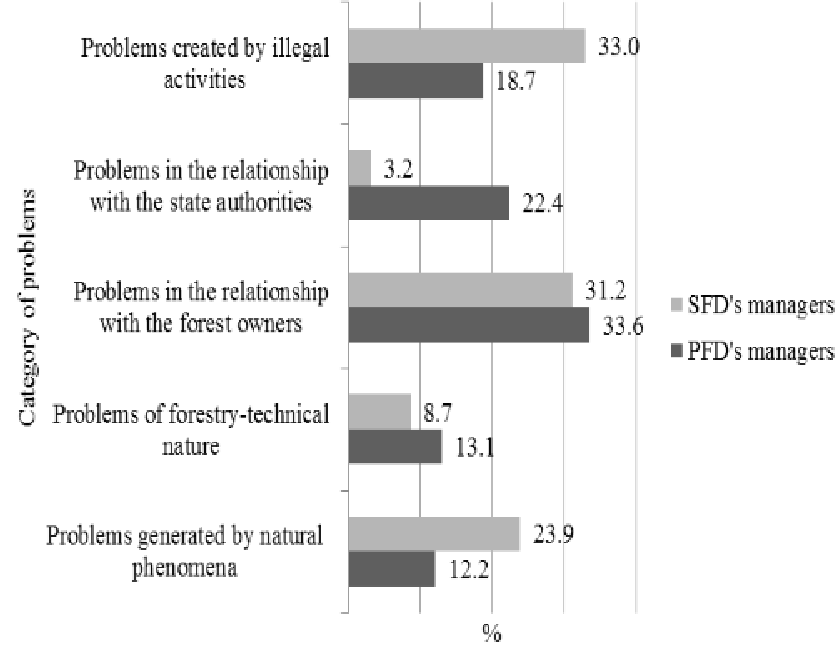

Fig. 9. The most frequent category of problems of forest districts covered by the study ( 163 from state and 63 from private forest districts) considered illegal logging and transport of wood as another encountered problem (Fig. 8). The main factors causing these frequent problems are, by importance: the population in social and economic need (111 responses), the gipsy population (67 responses), the forest owners and forestry sector economic operators. In private forest districts also grazing and deliberate forest fires were indicated as problems, caused by livestock owners and agricultural land owners.

\section{The category of problems with the greatest impact on forestry}

Problems concerning the relationship to forest owners rank first in the case of private forest district managers (Fig. 9). In the case of state forest districts top of the list of problems are the illegal activities, followed by problems concerning the relationship to forest owners. Generally, the problems encountered in the relationship to forest owners rank first with 104 responses, revealing the difference interests of forest owners and foresters where forest management is concerned.

\section{Necessary improvements}

As can be noticed in Tab. 2 and Tab. 3, the responses exceed $50 \%$ frequency only in two cases. Thus $57.7 \%$ of the state forest district managers deem that the relationship to the forest owners needs improving, and $50.5 \%$ of the private forest district managers consider that the involvement of the subordinated personnel needs improving. As to the rest of the signalled situations, percentages vary within a wide range. Interestingly, despite the merely short term experience in private property and the absence of professional training programmes, improvement of private forest owners competence level is not considered as opportune by the respondents (only $27 \%$ of the private and $13.7 \%$ of the state forest district managers have appreciated this opportunity). In exchange improvement of communication with forest owners is considered important in both categories of forest districts.

Regarding state institutions, improvement of communication with these is frequently requested by private forest district managers, unlike state forest district managers. In the case of logging companies, improvement of activity and competence appear to be deemed as opportune by both categories of managers, particularly by those of private forest districts.

Improvement of forest management personnel competence is recommended by $43.2 \%$ of the private forest district managers, and better communication with the civil society is deemed opportune by $45.9 \%$ of the private and $43.2 \%$ of the state forest district managers. Better communication with and more active involvement of the academia is considered necessary by $41.4 \%$ and $45.9 \%$ of the private forest district managers, respectively, while these percentages are smaller in the case of state forest district managers. The competence of the political parties whose representatives are responsible for the passed legislation and norms is a request issued by $40.5 \%$ of the private forest district managers.

It should be pointed out that the necessity of improving activity, competence, communication, and involvement is signalled by private forest district managers for 8 of the 9 categories of factors of interest (Tab. 2) in clearly higher percentages than done by state forest district managers. This proves that the representatives of the private forest districts have higher requirements and expectations of the factors of interest with whom they interact. 
Tab. 2. Characteristics that need to be improved by the factors of interest for private forest districts (\% of the total responses)

\begin{tabular}{|c|c|c|c|c|}
\hline Characteristic & Activity & Competence & Communication & Involvement \\
\hline Forest district personnel & 22.5 & 27.9 & 18.9 & 50.5 \\
\hline Forest owners & 6.3 & 27 & 46.8 & 29.9 \\
\hline State institutions & 3.5 & 36 & 49.5 & 34.2 \\
\hline Logging companies & 40.5 & 47.7 & 9 & 12.6 \\
\hline Forest management companies & 25.2 & 43.2 & 16.2 & 21.6 \\
\hline Civil society & 9 & 15.3 & 45.9 & 34.2 \\
\hline Administrators of protected areas & 17.1 & 24.3 & 45.9 & 26.1 \\
\hline Academia & 7.2 & 5.4 & 41.4 & 45.9 \\
\hline Political parties & 12.6 & 40.5 & 29.7 & 22.5 \\
\hline
\end{tabular}

Tab. 3. Characteristics that need to be improved by the factors of interest for state forest districts (\% of the total responses)

\begin{tabular}{|c|c|c|c|c|}
\hline Characteristic & Activity & Competence & Communication & Involvement \\
\hline Forest district personnel & 13.2 & 20.9 & 22.6 & 45.3 \\
\hline Forest owners & 6.4 & 13.7 & 57.7 & 24.3 \\
\hline State institutions & 9.8 & 15.4 & 32.9 & 35.9 \\
\hline Logging companies & 44 & 35 & 15 & 17.1 \\
\hline Forest management companies & 20.9 & 31.2 & 15.4 & 29.1 \\
\hline Civil society & 11.5 & 7.7 & 43.2 & 29.9 \\
\hline Administrators of protected areas & 11.5 & 10.3 & 44.9 & 22.6 \\
\hline Academia & 7.7 & 2.6 & 35 & 35.9 \\
\hline Political parties & 7.7 & 30.3 & 23.1 & 13.7 \\
\hline
\end{tabular}

\section{Conclusions}

Despite the fact that the forest land restitution process in Romania is far from being completed, the changes in forest management have known a dramatic evolution. Particularly the new owners of vast forest lands, encouraged by the new legislative framework have considered that leaving the administrative monopoly of Romsilva can be achieved by establishing own forestry structures, i.e. private forest districts, and have consequently displayed a - most certainly not anticipated - level of implication in promoting their interests through these structures. Despite the inherent difficulties of establishing and kick-starting the activity of private forest districts, the owners and forestry personnel have succeeded in achieving the current situation, where $57 \%$ of the non-state forest lands are administered by private forest districts. This is indicative of the steadily growing influence of these new structures in the management of forest lands in Romania.

In the view of forest district managers the improvement of communication between the various factors involved in forest land management is a necessity. Despite the large number of valid responses, the tendency revealed by this study is that of the forest district managers' growing interest for a better adaptation to the problems that occur. The fact that the majority of the representatives of AAP member forest districts have returned valid responses confirms the benefits of associating and dialogue with the civil society regarding communication, increased interest, information and involvement.

The lack or low quality of management for small owners, as well as the fragmentation of forest property most often yield technical silvicultural problems for forest district activity. Making profits from breaching forestry regime and not honouring forestry services contracts are also frequent problems in connection with the relationship to forest owners. Exercising adequate promptness in responding to various requests, improved communication, efficient guidance and less frequent inspections are the desiderata and expectations of private forest district managers from state institutions. In the view of 178 forest district managers, harmonising forestry regulations with the social and economic needs of the population, as well as addressing in a realistic manner the problems of the gipsy population from certain rural communities could reduce illegal cuttings and transport of wood.

As a conclusion, the real, concrete problems faced by foresters and most of all the structure and ownership related characteristics of national forestland need to become the driving force of changes in forestry legislation and beyond.

\section{Acknowledgments}

This paper is supported by the Sectoral Operational Programme Human Resources Development (SOP HRD), ID134378 financed from the European Social Fund and by the Romanian Government.

\section{References}

Abrudan IV (2012). A Decade of Non-State Administration of Forests in Romania: Achievements and Challenges. International Forestry Review.14(3):275-284.

Abrudan IV, Dutca I (2006). Database of private forest districts from Romania - MS Excel. Transilvania Univ Brasov, Romania (in Romanian).

Abrudan IV, Marinescu V, Ionescu O, Ioras F, Horodnic SA, Sestras R (2009). Developments in the Romanian Forestry and its Linkages with other Sectors. Not Bot Horti Agrobo 37:14-21.

Babbie E (2010). The Practice of Social Research. Eleventh Edition, Polirom, Bucureşti, Romanian translation published by Polirom. Bucureşti.

Bouriaud L (2008). Forest Property and Property Right between Restitution and Re-composition. Analele Universității "Ștefan Cel Mare” Suceava. Section Silviculture 3 (in Romanian). 
595

Bouriaud L, Schmithusen F (2005). Allocation of Property Rights on Forests through Ownership Reform and Forest Policies in Central and Eastern European Countries. Schweizerische Zeitschrift für Forstwesen 156(8):297-305.

Bouriaud L (2001). Sustainable Forest Management: with or without Privately Owned Forests? A Romanian Case Survey. Economic Sustainability of Small-Scale Forestry. EFI Proceedings 36.

Chelcea S (2001). Academic textbook: Techniques of Sociological Research. Șc Națion Studii Polit Administr Bucureşti (in Romanian).

Curtea de Conturi a Romaniei [Romanian Court of Accounts RCA] (2013). Sinteza Raportului de audit privind "Situația patrimonială a fondului forestier din România, în perioada 1990-2012" [Summary of the audit report on the "Situation of the forest land patrimony in Romania in the period 19902012"]. http://www.curteadeconturi.ro.

Institutul Național de Statistică [National Institute for Statistics] (2013). https://statistici.inss.ro.

Ioras F, Abrudan IV (2006). The Romanian forestry sector: privatization facts. International Forestry Review 8:361-367.

Lawrence A, Szabo A (2005). Forest Restitution in Romania: Challenging the Value System of Foresters and Farmers. Environmental Change Institute. University of Oxford. UK.

Machedon I, Androne S, Enășescu Ș, Popa A (1999). Codul Silvic [Forestry Law] (Law no. 26/1996). Editura Tridona-Oltenița.

Marinchescu M, Hălălișan AF (2014). A Review of Romanian Forestry Sector. Book of Abstracts. 13th International Symposium "Prospects for the 3rd Millennium Agriculture". Cluj-Napoca, p. 686.

Marinchescu M, Hălălișan AF, Ioraș F, Abrudan IV (2013). Romanian Private Forest Districts - Between Production and Biodiversity Conservation. Annals of the Academy of Romanian Scientists. Series on Agriculture, Silviculture and Veterinary Medicine Sciences 2(1) (accepted paper).
Marinescu V (2005). Coherence of the Romanian Forestry Regulations System in the Context of Forest Ownership Category Diversification as an Aim in Achieving Sustainable Forest Management, p. 601-608. In: Proceedings of the Scientific Symposium 'Forests and Sustainable Development'. Transilvania Univ Braşov, Faculty of Silviculture and Forest Engineering. Ed Univ Transilvania Braşov.

Marinescu V (2007). Changes in the Property Structure of the Forests in Romania as Generating Compulsions in the Elaboration of a Viable Forest Policy, p. 639-646. In: Proceedings of the Scientific Symposium 'Forests and Sustainable Development'. Transilvania Univ Braşov, Faculty of Silviculture and Forest Engineering. Ed Univ Transilvania Braşov.

Marsden PV, Wright JD (2010). Handbook of Survey Research. 2nd Edition. Emerald Group Publishing Ltd., UK.

Mărginean I (2000). Design of Sociological Research. Editura Polirom, Iași (in Romanian).

Poynton S, Mitchell A, Ionașcu G, McKinnenn F, Elliott J, Abrudan IV (2000). Economic Evaluation and Reform of the Romanian Forestry Sector. Braşov, Romania.

RNP Romsilva [The National Forest Administration]: Rapoarte finale sau parțiale de activitate a RNP Romsilva [Final or Partial Activity Reports of Romsilva] (2012, 2013, 2014). https://www.romsilva.ro.

Tobescu C (2004). Private Forest Districts - the Result of 14 Years of Evolution. http://www.forestry.ro/ (in Romanian).

UNECE. FAO (2011). The European Forest Sector Outlook Study II, 2010-2030. Sales No. E. 11. II E. 14.

Ungur A (2008). Romanian Forests: Past, Present and Future Policies and Strategies. Bucureşti. Editura, Devadata (in Romanian).

Weiss G, Guduric I, Wolfslehner B (2012). Review of forest owners' organizations in selected Eastern European countries. FAO, Forestry Policy and Institutions Working Paper 30. Rome. 